\title{
IMPLEMENTASI PROGRAM PEMBINAAN KARAKTER SANTRI MELALUI WORKSHOP DAN FIELD TRIP DI PESANTREN MODERN
}

\author{
Nurti Budiyanti \\ Universitas Pendidikan Indonesia \\ nurtibudiyanti@,upi.edu
}

\author{
Asep Abdul Aziz \\ UIN Sunan Gunung Djati Bandung \\ asepabdulaziz1993@gmail.com \\ Andewi Suhartini \\ UIN Sunan Gunung Djati Bandung \\ andewisuhartini@,uinsgd.ac.id \\ Nurwadjah Ahmad \\ UIN Sunan Gunung Djati Bandung \\ nurwadjahahmad@,uinsgd.ac.id
}

\begin{abstract}
The character of Islam needs to be nurtured early on in overcoming increasingly degrading moral degradation. One of the educational institutions that has a big role in fostering character is pesantren. Pesantren Kreatif IHAQI Boarding School Bandung is one of the pesantren educational institutions present in the era of industrial revolution 4.0. This pesantren has different characteristics in the process of building santri character. This research uses qualitative approach with case study method at IHAQI Boarding School Bandung Creative Boarding School. The results of the study illustrate that the coaching program presented at IHAQI Boarding School Creative Boarding School is a KBM program, islamic character habituation, self-development and life skills, weekly coaching, monthly


coaching, creative coaching, and pesantrenan coaching. From a number of programs presented there are excellent programs that are always anticipated by all students as well as parents of students in the pesantren environment. There are two excellent programs in pesantren, namely workshop and filed trip. This excellent activity in pesantren is a unique and creative activity in developing life skills, both acting, working and speaking skills. This skill is aimed at the formation of santri character, so that students can behave in accordance with Islamic values based on the experience, knowledge and examples of educators.

Keywords: Coaching; character; implementation; programme; pesantren.

\section{PENDAHULUAN}

Pendidikan memiliki tanggung jawab yang sangat besar dalam mewujudkan generasi yang berkarakter Islami. Berbagai isu mengenai pendidikan karakter sangat tajam dibicarakan oleh para pakar pendidikan, realita kini menggambarkan semakin derasnya degradasi moral bangsa di setiap jenjang pendidikan. Hal ini disebabkan antara lain karena banyak sekolah di Indonesia hanya sebatas memindahkan ilmu pengetahuan saja, dan belum sampai pada taraf pembentukan moral dan etika (character building). ${ }^{1}$ Pembentukan karakter harus dilakukan secara sistematis dan berkesinambungan yang melibatkan aspek knowledge, feeling, loving dan action. Sehingga pembelajaran tidak bersifat parsial, perlu diupayakan pembelajaran integratif serta komprehensif dalam membantuk karakter Islami. $^{2}$

Salah satu institusi pendidikan yang disinyalir telah lama menerapkan pendidikan karakter adalah pondok pesantren. Pondok Pesantren sebagai salah satu sub-sistem Pendidikan Nasional dipandang oleh banyak kalangan mempunyai keunggulan dan karakteristik khusus dalam mengaplikasikan pendidikan karakter bagi peserta didik. Proses pengembangan dunia pesantren harus di dukung oleh pemerintah secara serius sebagai proses pembangunan manusia seutuhnya. Meningkatkan dan mengembangkan peran pesantren dalam proses pembangunan di era

\footnotetext{
${ }^{1}$ Imam Syafe'i. "Pondok Pesantren: Lembaga Pendidikan Pembentukan Karakter." AlTadrkiyyah: Jurnal Pendidikan Islam 8, no. 1 (2017), hlm. 61.

2 Iyus Herdiana. “The Development of Character Education Model Based on Human's Natural Characteristics” (2013), hlm. 264-271.
} 
otonomi daerah merupakan langkah strategis dalam upaya mewujudkan tujuan pembangunan nasional terutama sektor pendidikan.

Pesantren sebagai lembaga pendidikan membentuk dan mengembangkan nilai-nilai moral menjadi pelopor sekaligus inspirator pembangkit moral bangsa. Sejatinya perkembangan pendidikan pondok pesantren merupakan perwujudan dari kebutuhan masyarakat akan suatu sistem pendidikan alternative. ${ }^{3}$ Pesantren memiliki akar historis yang cukup kuat sehingga menduduki posisi relatif sentral dalam dunia keilmuan. ${ }^{4}$ Keberadaan pondok pesantren di Indonesia, dalam perkembangannya sangat berpengaruh terhadap masyarakat di sekitarnya, terutama dalam hal pendidikan. ${ }^{5}$ Hal ini disebabkan bahwa dari sejak awal berdirinya pesantren disiapkan untuk mendidik dan menyebarkan ajaran Islam kepada masyarakat melalui pengajian, baik dengan sistem tradisional maupun modern. Hal ini mengisyaratkan bahwa sistem pendidikan pesantren memiliki komitmen kuat dalam mengokohkan karakter manusia agar memiliki pribadi yang utuh di hadapan Allah. ${ }^{6}$

Berdasarkan pemaparan di atas, pesantren telah membuktikan dirinya sebagai suatu lembaga pendidikan Islam yang established (mapan) dan memiliki posisi strategis dalam dunia pendidikan di Indonesia, karena memililki peran untuk membentuk karakter manusia utuh. ${ }^{7}$ Dalam menjalankan perannya terebut, maka penting kiranya penulis melakukan sebuah penelitian terhadap salah satu pesantren yang ada di Indonesia berkaitan berbagai upaya pembinaan karakter santri di Pesantren Kreatif IHAQI Boarding School Bandung. Berdasarkan studi pendahuluan pesantren ini merupakan salah satu pesantren yang baru yang berada di wilayah perbatasan antara Kota Bandung dan Kabupaten Bandung yang berdiri pada tahun 2017 yang lalu, pesantren ini dibina oleh salah satu Ustadz ternama yang ada di Indonesia yakni Ustadz Erick Yusuf, beliau merupakan salah satu ulama nasional juga internasional juga seorang publik figur. Pesantren ini memiliki ciri khas yang berbeda dengan yang lain, hal ini terlihat dari pelaksanaan dua program unggulan Pesantren yaitu Workshop dan Field Trip. Kekhasan inilah yang sejatinya

3 Alwi, B. Marjani. "Pondok Pesantren: Ciri Khas, Perkembangan, dan Sistem Pendidikannya." Lentera Pendidikan: Jurnal Ilmu Tarbiyah dan Keguruan 16, no. 2 (2016), hlm. 205-219.

${ }^{4}$ Bashori. "Modernisasi Lembaga Pendidikan Pesantren." Jurnal Ilmu Sosial Mamangan 6, no. 1 (2017), hlm. 47.

5 Sulaiman, Rusydi. "Hakikat Pendidikan Pesantren." Edugama: Jurnal Kependidikan dan Sosial Keagamaan 5, no. 1 (2019), hlm. 11-20.

6 Nihwan. "Pendidikan Pesantren dalam Mempertahankan Nilai-Nilai Pendidikan Islam.” Jurnal Studi Keagamaan, Pendidikan dan Humaniora 4, no. 1 (2017), hlm. 151-165.

${ }^{7}$ Rusydi. "Hakikat Pendidikan Pesantren.", hlm. 12. 
menjadi bahan analisis penulis dalam menggambarkan upaya pembinaan karakter santri di era revolusi industri 4.0.

\section{METODE PENELITIAN}

Studi ini bertujuan untuk memperoleh gambaran mengenai upaya pembinaan karakter santri melalui Worksop dan Field Trip di Pesantren Kreatif IHAQI Boarding School Bandung. Penelitian ini menggunakan pendekatan kualitatif dengan metode studi kasus. ${ }^{8}$ Dalam penelitian dilakukan penelusuran data tentang berbagai upaya pembinaan karakter santri yang menjadi objek studi kasusnya berfokus pada Pesantren Kreatif IHAQI Boarding School Bandung. Penelitian studi kasus yaitu suatu strategi riset, penelaahan empiris yang menyelidiki suatu gejala dalam latar kehidupan nyata. ${ }^{9}$ Strategi ini dapat menyertakan bukti kualitatif yang bersandar pada berbagai sumber dan perkembangan sebelumnya dari proposisi teoretis. Peneliti menghimpun, mengidentifikasi, menganalisis, dan mengadakan sintesis data, ${ }^{10}$ untuk kemudian memberikan interpretasi terhadap berbagai upaya pembinaan karakter santri di Pesantren Kreatif IHAQI Boarding School Bandung.

\section{PESANTREN SEBAGAI LEMBAGA PENDIDIKAN KARAKTER SEPANJANG MASA}

Pesantren merupakan lembaga pendidikan tertua di Indonesia. Pesantren adalah bentuk pendidikan tradisional di Indonesia yang sejarahnya telah mengakar secara berabad-abad jauh sebelum Indonesia merdeka dan sebelum kerajaan Islam berdiri. ${ }^{11}$ Istilah pesantren dan pondok merupakan dua kata yang tidak bisa dipisahkan, karena setiap membahas pesantren berarti kita sedang membahas konsep pondok di dalamnya. ${ }^{12}$ Secara etimologi istilah pondok sebenarnya berasal dari bahasa Arab, funduq yang berarti rumah penginapan, ruang tidur, asrama, atau wisma sederhana. ${ }^{13}$ Adapun secara terminologis kata pondok seringkali dipahami sebagai tempat penampungan sederhana bagi para

\footnotetext{
${ }^{8}$ Lexy J. Moleong, "Metodologi Penelitian Kualitatif (Edisi Revisi)," in PT. Remaja Rosda Karya, 2017, hlm. 37.

9 Sugiyono, Metode Penelitian Kuantitatif, Kualitatif Dan R\&D, 24th ed. (Bandung: Alfabeta, 2016), hlm. 28.

10 M. B. Miles and A. M. Huberman, Qualitative Data Analysis, Second Edi. (London: SAGE Publications, Inc., 1994), hlm. 145.

11 Busahdiar. "Dinamika Pendidikan di Pesantren." Misykat al-Anwar Jurnal Kajian Islam dan Masyarakat 27, no. 2 (2016), hlm. 1-12.

12 Ahmad Masrul Anwar. "Pertumbuhan dan Perkembangan Pendidikan Islam Pada Masa Bani Ummayah." Jurnal TARBIYA 1, no. 1 (2015), hlm. 47-76.

${ }^{13}$ Herman. "Sejarah Pesantren Di Indonesia." Jurnal Al-Ta'dib 6, no. 2 (2013), hlm. 145158.
} 
pelajar atau santri yang jauh dari tempat asalnya. ${ }^{14}$ Sementara menurut pendapat Sugarda Poerbawakatja pondok adalah suatu tempat pemondokan bagi pemuda-pemudi yang mengikuti pelajaran-pelajaran agama Islam. Inti dan realitas pondok tersebut adalah kesederhanaan dan tempat tinggal sementara bagi para penuntut ilmu. ${ }^{15}$

Tujuan dibentuknya pondok pesantren adalah: ${ }^{16}$ (1) Mencetak ulama yang menguasai ilmu-ilmu agama. (2) Mendidik muslim yang dapat melaksanakan syariat agama. (3) Mendidik agar objek memiliki keterampilan dasar yang relevan dengan terbentuknya masyarakat beragama. ${ }^{17}$ Semantara itu, tujuan khususnya yaitu mempersiapkan para santri untuk menjadi orang yang alim dalam ilmu agama yang diajarkan oleh kyai yang bersangkutan serta mengamalkannnya dalam masyarakat. ${ }^{18}$ Dengan demikian tujuan pendidikan pesantren adalah mencetak santri yang tafaquh fid diin (faham terhadap agama), mampu mengembangkan potensi intelektual, emosional dan spiritual dengan baik dalam kehidupan sahari-hari. ${ }^{19}$

Pesantren sebagai salah satu lembaga pendidikan Islam di Indonesia memiliki karakteristik yang khusus dan potensi yang dimiliki para santri yang meliputi: (1) Kemandirian: kemandirian tingkah-laku adalah kemampuan santri untuk mengambil dan melaksanakan keputusan secara mandiri, misalnya pengelolaan keuangan, perencanaan belanja, perencanaan aktivitas rutin, dan sebagainya. Hal ini tidak lepas dari kehidupan mereka yang tidak tinggal bersama orangtua mereka dan tuntutan pesantren yang menginginkan santri-santri dapat hidup dengan berdikari. (2) Keikhlasan: segala perbuatan dilakukan semata-mata karena untuk ibadah lillah. ${ }^{20}$ (3) Toleransi: toleransi dipandang bisa menjadi

14 Ari Prayoga, Irawan Irawan, dan Ahmad Rusdiana, "Karakteristik Program Kurikulum Pondok Pesantren," Jurnal Pendidikan dan Pendidikan Agama Islam 02, no. 01 (June 2020), hlm. 77-86.

15 Maesaroh, Nenden, dan Yani Achdiani. "Tugas dan Fungsi Pesantren di Era Modern." Sosietas 7, no. 1 (2018), hlm. 346-352.

16 Zulhimma. "Dinamika Perkembangan Pondok Pesantren di Indonesia." Jurnal Darul 'Ilmi 01, no. 02 (2013), hlm. 166-167.

${ }^{17}$ Nilna Azizatus Shofiyyah, Haidir Ali, dan Nurhayati Sastraatmadja, "Model Pondok Pesantren di Era Milenial," BELAJEA: Jurnal Pendidikan Islam 4, no. 1 (2019, hlm. 1.

18 Abdul Tolib, "Pendidikan di Pondok Pesantren Modern Terpadu," Risalab 1, no. 1 (2015), hlm. 60-66.

19 Andewi Suhartini. "The Internalization of Islamic Values in Pesantren." Jurnal Pendidikan Islam (2016), hlm. 287-305.

${ }^{20}$ Anzar Abdullah. "Madrasah di Indonesia dari Masa." Paramita 23, no. 2 (2013), hlm. 193-207. 
perekat persatuan bangsa Indonesia yang harus dibina dengan baik. ${ }^{21}$ (4) Kesederhanaan: sederhana di sini bukan berarti pasif, melarat, atau miskin, melainkan mengandung unsur kekuatan hati, ketabahan, dan pengendalian diri di dalam mengahadapi bebagai macam rintangan hidup sehingga diharapkan akan terbit jiwa yang besar, berani, begerak maju, dan pantang mundur dalam segala keadaan. ${ }^{22}$ (5) Ukhuwah Islamiyyah: suasana kehidupan di pondok pesantren selalu diliputi semangat persaudaraan yang sangat akrab sehingga susah dan senang tampak dirasakan bersama tentunya, terdapat banyak nilai-nilai keagamaan yang telah akrab di dalamnya. ${ }^{23}$

Penerapan karakter religius sangat dibutuhkan untuk menghadapi permasalahan-permasalahan yang menghancurkan sistem kemanusiaan, penerapan keagamaan merupakan pembinaan secara keselurhaan yang membutuhkan tenaga, kesabaran, ketelatenan, ruang, waktu dan biaya yang ekstra guna menjadi jembataan dalam Negara sebagai perwujudkan manusia utuh yang senantiasa bertakwa kepada Allah SWT. ${ }^{24}$ Dengan demikian, karakter religius inilah yang harus senantiasa ditumbuhkan di pondok pesantren, karena di sinilah awal tumbuhnya kekuatan mental dan karakter yang menjadi syarat bagi suksesnya suatu pejuangan dalam segala bidang kehidupan. ${ }^{25}$

\section{PESANTREN KREATIF IHAQI BOARDING SCHOOL SEBAGAI PESANTREN DI ERA REVOLUSI INDUSTRI 4.0}

Perkembangan pesantren dari masa ke masa memiliki perubahan yang sangat signifikan, terlebih dunia kini sedang merespon percepatan revolusi industry 4.0 yang memiliki kecanggihan teknologi yang semakin pesat. $^{26}$ Salah satu lembaga pendidikan pesantren yang hadir di era revolusi industri 4.0 ialah Pesantren Kreatif IHAQI Boarding School Bandung. Pesantren ini adalah pesantren yang memadukan berbagai

${ }^{21}$ H. A. Rodli Makmun. "Pembentukan Karakter Berbasis Pendidikan Pesantren: Studi di Pondok Pesantren Tradisional dan Modern di Kabupaten Ponorogo." Cendekia: Jurnal Kependidikan dan Kemasyarakatan 12, no. 2 (2016), hlm. 211.

22 Rusydi. "Hakikat Pendidikan Pesantren.", hlm. 13-14.

23 Siregar, Andre Syahbana. "Sejarah Perkembangan Sistem Pendidikan Islam di Pesantren Ar-Raudlatul Hasanah Kota Medan.” JUSPI (Jurnal Sejarah Peradaban Islam) 2, no. 1 (2018), hlm. 113.

24 Jannah, Miftahul. "Metode dan Strategi Pembentukan Karakter Religius yang Diterapkan di SDTQ-T An Najah Pondok Pesantren Cindai Alus Martapura." AlMadrasab: Jurnal Pendidikan Madrasah Ibtidaiyah 4, no. 1 (2019), hlm. 77.

25 Asep Abdul Aziz et al., "Pendidikan Islam Sebagai Upaya Ma'rifatullah," Adaara: Jurnal Manajemen Pendidikan Islam 10, no. 2 (August 2020), hlm. 174-186.

${ }^{26}$ Delipiter Lase. "Pendidikan di Era Revolusi Industri 4.0." SUNDERMANN: Jurnal Ilmiah Teologi, Pendidikan, Sains, Humaniora dan Kebudayaan (2019), hlm. 28-43. 
teknologi modern dalam proses pembelajaran serta mengembangkan berbagai disiplin keilmuan dan keterampilan yang dibutuhkan tanpa menghilangkan nilai-nilai Islam. ${ }^{27}$

Gambar 1: Pemilik Yayasan Pesantren Kreatif IHAQI Boarding School Bandung

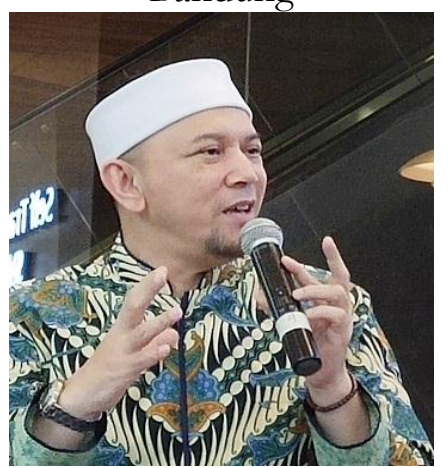

Gambar di atas merupakan tokoh ulama pendiri Pesantren Kreatif IHAQI Boarding School Bandung yang bernama Ustadz Erick Yusuf. Pesantren ini berdiri pada tahun 2017. Ustadz Erick menginginkan lembaga pendidikan komprehensif-holistik yang tidak hanya kental dengan nuansa Islami, namun juga melek dengan perkembangan zaman baik dari segi teknologi maupun kreativitas. Dari ide tersebut, lahirlah Pesantren Kreatif IHAQI Boarding School. Ustadz Erick yang memprakarsai berdirinya pesantren ini benar-benar mematangkan konsep pendidikan yang akan dibangun. Hal ini terbukti dari tenaga didik yang semuanya lulusan S2. Para pengajar yang profesional tersebut juga memiliki kompetensi dan kualifikasi tinggi di bidang pendidikan.

Gambar 2: Lokasi Depan Pesantren Kreatif IHAQI Boarding School Bandung
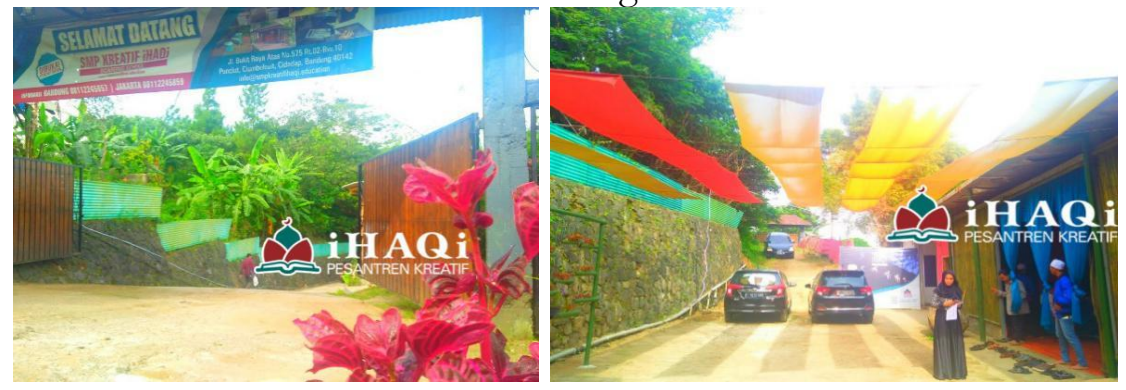

27 Ari Prayoga dan Mohammad Sulhan, "Pesantren Sebagai Penangkal Radikalisme dan Terorisme," Dirasat: Jurnal Manajemen dan Pendidikan Islam 5, no. 2 (December 2019), hlm. 163-177. 
Pesantren Kreatif IHAQI Boarding School secara geografis terletak di Kota Madya Bandung, bertepatan di jalan Bukit Raya atas No. 575 Rt 02 Rw 010 Punclut Ciumbeleuit Cidadap Bandung. Keberadaan lembaga pendidikan pesantren ini berada di wilayah yang cukup strategis, berada di perbatasan antara Kota Bandung dan Kabupaten Bandung. Dengan luas tanah $8000 \mathrm{M}^{2}$, status guna pakai dan luas bangunan $2000 \mathrm{M}^{2}$. Pesantren ini sudah memiliki akta pendirian yayasan dan surat izin yang legal, untuk melakukan proses pembelajaran. Adapun jumlah siswa sampai saat ini sudah mencapai 50 siswa, diberbagai tingkatan kelulusan dan kelas. Sistem Boarding School bukan sesuatu yang baru dalam konteks pendidikan di Indonesia. Karena suda sejak lama lembaga-lembaga pendidikan di Indonesia menghadirkan konsep pendidikan Boarding School yang mengadopsi "pondok pesanten" Boarding School yang pola pendidikannya lebih komprehensif-holistik lebih memungkinkan untuk menciptakan lingkungan pendidikan yang ideal untuk melahirkan orangorang yang akan dapat membawa revolusi pergerakan kehidupan sosial, politik, ekonomi dan agama. ${ }^{28}$ Sebagaimana hal ini dinyatakan oleh para pakar pendidikan bahwa kemampuan yang harus dihadapi peserta didik dalam menghadari era revolusi indstri ialah kemampuan yang berujung pada karakter abad 21 yakni Critical thinking, Creative, Communication, dan Colaborative. $^{29}$

Pesantren ini memiliki motto: "dengan ilmu dan akhlak sukses dunia akhirat". Dengan visi : agamis, universal dan kreatif. Agamis dalam artian segala idea pikiran dan tindak tanduk serta aktivitas perilaku seluruhnya mestilah terikat pada nilai-nilai agamis yang tentunya akan membawa kebaikan dunia dan akhirat, lalu universal adalah dimana seluruh civitas akademi dari mulai guru, ustadz, staff karyawan, siswa, wali siswa semua mestilah mempunyai wawasan yang universal karena dengannya kita dapat berhubungan dengan baik saling bertukar manfaat atau interkoneksi positif baik terhadap manusia, hewan maupun dengan alam., dan nilai kreatif adalah salah satu sifat Rasul Nabi Muhammad SAW yaitu fathonah. Nilai kreatif yang dapat diartikan cerdas dan penuh dengan ide dan selalu mendapatkan solusi dari berbagai tantangan yang menghampiri. Adapun misi Pesantren Kreatif IHAQI Boarding School dijabarkan sebagai berikut: (1) Menumbuhkan dan meningkatkan keimanan dan ketakwaan. (2) Melaksanakan ibadah dengan benar sesuai

\footnotetext{
${ }^{28}$ Maulia Depriya Kembara, Rama Wijaya Abdul Rozak, dan Vini Agustiani Hadian. "Research-Based Lectures to Improve Students' 4C (Communication, Collaboration, Critical Thinking, and Creativity) Skills" 306, no. Isseh 2018 (2019), hlm. 22-26.

${ }^{29}$ Resti Septikasari, dan Rendy Nugraha Frasandy. "Keterampilan 4C Abad 21 dalam Pembelajaran Pendidikan Dasar." Tarbiyah Al-Awlad VIII, no. 2 (2018), hlm. 112-122.
}

60 Muróbbî: Jurnal Ilmu Pendidikan 
dengan tuntutan Nabi Muhammad SAW. (3) Mengaplikasikan nilai-nilai agama dalam kehidupan sehari-hari. (4) Menguasai berbagai disiplin ilmu, baik agama maupun umum. (5) Menjadikan agama dan ilmu sebagai landasan hidup. (5) Menumbuhkan kreativitas dalam kehidupan. (6) Menjunjung tinggi dan mengaplikasikan nilai akhlak. (7) Menumbuhkan kemandirian dalam kehidupan. (8) Meningkatkan potensi keterampilan. Dengan demikian, visi misi pesantren ini diarahkan mengikuti perkembangan zaman revolusi industry 4.0.

\section{UPAYA PEMBINAAN KARAKTER SANTRI DI PESANTREN KREATIF IHAQI BOARDING SCHOOL BANDUNG}

Pesantren Kreatif IHAQI berkeinginan untuk menghadirkan konsep pendidikan Islami yang religius namun juga sesuai dengan perkembangan zaman. Konsep yang diterapkan dalam Pesantren Kreatif IHAQI adalah stepping stone; yaitu, pembelajaran secara bertahap sehingga para santri tidak perlu takut atau minder akan ketinggalan materi pelajaran. Sebagaimana yang dinyatakan oleh para pakar pendidikan bahwa proses pembelajaran yang dilakukan peserta didik harus senantiasa menyesuaikan dengan kemampuan yang dimiliki. ${ }^{30}$ Sejatinya santri merupakan peserta didik yang sedang berjuang dalam mengembangkan seluruh potensi yang Allah berikan pada dirinya ${ }^{31}$, potensi ini harus diarahkan melalui bimbingan Al-Quran dan Hadis sebagai pedoman hidup manusia. ${ }^{32}$

Proses pendidikan yang diutamakan di pesantren ini bukan hanya transfer ilmu saja, tetapi juga pembentukan karakter melalui pemberian teladan yang baik oleh para pendidik handal yang merupakan lulusan strata 2 (S2). Penguasaan bahasa mutlak untuk dipelajari, para santri diarahkan untuk bisa menguasai tiga bahasa yaitu Arab, Inggris, dan Indonesia ${ }^{33}$ sehingga para santri lulusan Pesantren Kreatif IHAQI diharapkan dapat berdakwah dengan cara modern yang cantik dikemas

30 Humaira Ulfah, Edi Suresman, dan Abas Asyafah. "Studi Realitas Implementasi Kurikulum 2013 Pada Mata Pelajaran PAI dan Budi Pekerti Jenjang SMA (Studi Deskriptif Pada Berbagai Klasifikasi Guru SMA Di Kota Bandung Tahun 2015).” TARBAWY : Indonesian Journal of Islamic Education (2015), hlm. 58-67.

31 Musaddad Harahap. "Esensi Peserta Didik dalam Perspektif Pendidikan Islam." Jurnal Al-Thariqah Fakultas Agama Islam (FAI) Universitas Islam Riau (UIR) Pekanbaru Jl. Kaharuddin Nasution 1, no. 113 (2016), hlm. 140-155.

${ }^{32}$ Muh. Khoirul Rifa'i, "Internalisasi Nilai-Nilai Religius Berbasis Multikultural dalam Membentuk Insan Kamil," Jurnal Pendidikan Agama Islam Journal of Islamic Education Studies) (2016), 116-133.

${ }_{33}$ Muhamad Parhan et al., "Internalization Values of Islamic Education At University," International Journal of Psychosocial Rehabilitation 24, no. 08 (2020): 14778-14791. 
dengan baik dan berwawasan. Adapun program pembinaan yang disajikan di Pesantren Kreatif IHAQI Boarding School ialah sebagai berikut:

Tabel 1: Program Pembinaan Pesantren Kreatif IHAQI Boarding School Bandung

\begin{tabular}{|c|c|c|}
\hline No & $\begin{array}{l}\text { Program } \\
\text { Pembinaan }\end{array}$ & Uraian \\
\hline 1. & $\begin{array}{l}\text { Pembinaan Proses } \\
\text { Pembelajaran }\end{array}$ & $\begin{array}{l}\text { Kegiatan pembinaan proses KBM } \\
\text { berlangsung pada pukul 07.15-14.20 WIB. } \\
\text { Setiap ruangan kelas dibatasi maksimal } 15 \\
\text { orang. Pesantren ini menyiapkan pendidik } \\
\text { professional sesuai bidang mata } \\
\text { pelajarannya masing-masing dengan } \\
\text { menggunakan kurikulum nasional juga } \\
\text { kurikulum pesantrean kreatif IHAQI. } \\
\text { Metode pembelajaran yang di digunakan } \\
\text { ialah pembelajaran edutainment, berbasis } \\
\text { projek, dan STEAM yang dilakukan melalui } \\
\text { pendekatan pembelajaran student-centered. } \\
\text { Adapun penguatan materi ilmu keagamaan } \\
\text { yaitu : aqidah akhlak, akhlak islam, fiqih, } \\
\text { sejarah Islam, bahasa arab, al-Qur'an } \\
\text { hadist, dan penguatan hapalan qur'an. }\end{array}$ \\
\hline 2. & $\begin{array}{l}\text { Pembiasaan } \\
\text { Pemeriharaan } \\
\text { Karakter Islam }\end{array}$ & $\begin{array}{l}\text { Kegiatan pembinaan dengan pembiasaan } \\
\text { pemeliharaan karakter Islam yang biasa } \\
\text { disebut dengan salim sholeh (5S) yakni } \\
\text { senyum, salam, sapa, sopan, santun di } \\
\text { pesantren ini sudah menjadi budaya yang } \\
\text { harus senantiasa dilakukan baik di } \\
\text { lingkungan sekolah maupun di luar } \\
\text { lingkungan sekolah. Selain itu pembiasaan } \\
\text { shalat dhuha, asmaul husna, tilawah } \\
\text { Qur'an, doa serta inspirasi pagi menjadi } \\
\text { kebiasaan wajib yang harus dilakukan para } \\
\text { santri di awal pembelajaran. Selain itu, } \\
\text { pembiasaan shalat sunnah (rawatib, dhuha, } \\
\text { tahajud), serta shaum sunnah (Senin-Kamis } \\
\text { dan Daud), shalat wajib berjamaah diawal } \\
\text { waktu, tadarus Al-Qur'an satu hari satu juz } \\
\text { merupakan pembiasaan yang harus } \\
\text { dilakukan setiap hari. Sementara, }\end{array}$ \\
\hline
\end{tabular}




\begin{tabular}{|c|c|c|}
\hline & & $\begin{array}{l}\text { pembiasaan literasi bacaan buku-buku } \\
\text { terdapat pengkhususan tersendiri yakni } \\
\text { pada hari Senin dan Selasa (bahasa } \\
\text { Indonesia), Rabu (bahasa Sunda), Kamis } \\
\text { (bahasa Inggris), Jum'at (bahasa Arab). }\end{array}$ \\
\hline 3. & $\begin{array}{l}\text { Pengembangan } \\
\text { Diri dan Life Skill }\end{array}$ & $\begin{array}{l}\text { Kegiatan pengembangan diri dilakukan } \\
\text { dengan tes psikologi dan inventaris catatan } \\
\text { perkembangan santri. Adapun program } \\
\text { yang disediakan dalam menunjang aktivias } \\
\text { pengembangan diri di pesantren ini ialah } \\
\text { layanan konsultasi belajar, kepribadian, } \\
\text { peminatan jurusan khusus untuk kelas 9, } \\
\text { serta pelatihan pengembangan diri dan } \\
\text { motivasi belajar (workhsop dan field trip) } \\
\text { yang ditujukan untuk pengembangan } \\
\text { karakter 4C: Critical thinking, Creative, } \\
\text { Communication, dan Colaborative. Kemudian } \\
\text { kegiatan Ekstrakulikuler seperti pramuka, } \\
\text { olahraga (panahan, futsal, dan renang), } \\
\text { kesenian (perkusi, teater, dan nasyid). }\end{array}$ \\
\hline 4. & $\begin{array}{l}\text { Pembinaan } \\
\text { Mingguan }\end{array}$ & $\begin{array}{l}\text { Kegiatan pembinaan mingguan yang } \\
\text { dilakukan di pesantren ini ialah kegiatan } \\
\text { kewalikelasan, keputrian dan keputraan } \\
\text { yang diselenggarakan setiap hari jumat, } \\
\text { pembinaan spiritual (PTHBI), mentoring } \\
\text { hifdzil Quran, muhadharah, shalat jum'at, } \\
\text { outing ahad, serta operasi semut asih (ahad } \\
\text { bersih). }\end{array}$ \\
\hline 5. & $\begin{array}{l}\text { Pembinaan } \\
\text { Bulanan }\end{array}$ & $\begin{array}{l}\text { Kegiatan pembinaan mingguan yang } \\
\text { dilakukan di pesantren ini ialah upaca } \\
\text { bendera (setiap tanggal 17, kecuali Sabtu } \\
\text { dan Ahad), Sharing profesi (oleh orang tua } \\
\text { peserta didik) (setiap pembagian rapor), } \\
\text { Student performance (setiap pembagian rapor, } \\
\text { Workshop dan field trip, Pesantren Trip, } \\
\text { Riblah, Jumat Berkah (Berbagi Sedekah), } \\
\text { Ubudiyah (Belajar Fiqh, setiap Ahad). }\end{array}$ \\
\hline
\end{tabular}




\begin{tabular}{|l|l|l|}
\hline 6. & $\begin{array}{l}\text { Pdapun pembinaan unggulan yang } \\
\text { Pembinaan }\end{array}$ & $\begin{array}{l}\text { Kilakukan di pesantren ini mengacu kepada } \\
\text { kurikulum kreatif seperti kegiatan prakarya, } \\
\text { desain publikasi, computer grafis, } \\
\text { photography, videography, produk kreatif, } \\
\text { kewirausahaan, serta musik religi. }\end{array}$ \\
\hline 7. & $\begin{array}{l}\text { Kegiatan kepesantrenan dilakukan secara } \\
\text { fulltime diluar proses pembelajaran } \\
\text { sekolah. Dimulai dari pukul 15.00- 06.00 } \\
\text { Kepesantrenan }\end{array}$ & $\begin{array}{l}\text { WIB. Adapun kegiatannya meliputi: shalat } \\
\text { tahajud, setoran hafalan, kajian Islam yang } \\
\text { berkaitan dengan pendalaman Al-Quran, } \\
\text { pendalaman Hadis, pendalaman sejarah } \\
\text { Islam, pendalaman akidah dan akhlak. }\end{array}$ \\
\hline
\end{tabular}

Tabel di atas menggambarkan rangkaian program pembinaan yang disajikan Pesantren Kreatif IHAQI Boarding School Bandung. Dari sejumlah rangkaian program yang disajikan terdapat program unggulan yang selalu dinantikan oleh seluruh santri juga orangtua santri yang ada di lingkungan pesantren. Terdapat dua program unggulan yang ada di Pesantren ini yakni: Pertama, kegiatan workshop yang dilakukan satu kali dalam satu bulan, dengan menghadirkan para tokoh ternama, baik itu tokoh agama, tokoh masyarakat, tokoh publik figur, serta para ilmuan yang sangat berkompeten dibidangnya. Kegiatan ini memiliki respon yang cukup positif dan memiliki dampak yang positif terhadap tumbuh kembang santri dalam mengembangkan diri serta life skill yang baik.

Gambar 3: Kegiatan Workshop Pesantren Kreatif IHAQI Boarding School Bandung

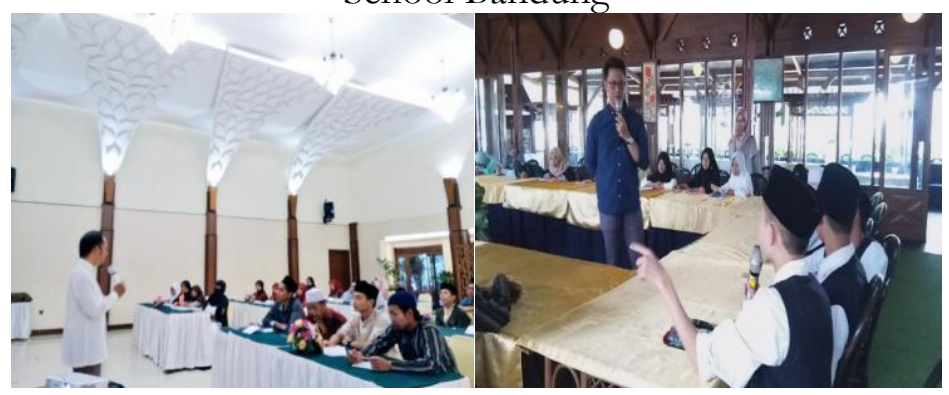

Kedua, kegiatan Field Trip yang dilakukan satu kali dalam satu bulan. Kegiatan ini dilakukan seperti berkunjung ke NET TV, berkunjung musiem, ke perusahaan besar yang memproduksi olahan susu sapi, olahan produksi makanan serta berkunjung ke perusahaan ternama lainnya yang ada di Jawa Barat. Kegiatan ini dipandang efektif 
untuk menumbuhkan daya ingat dan daya kreatif peserta didik, karena kegiatan ini dilakukan bertujuan untuk meningkatkan motovasi belajar serta mengembangkan minat dan bakat para santri.

Gambar 4: Kegiatan Field Trip Pesantren Kreatif IHAQI Boarding School Bandung
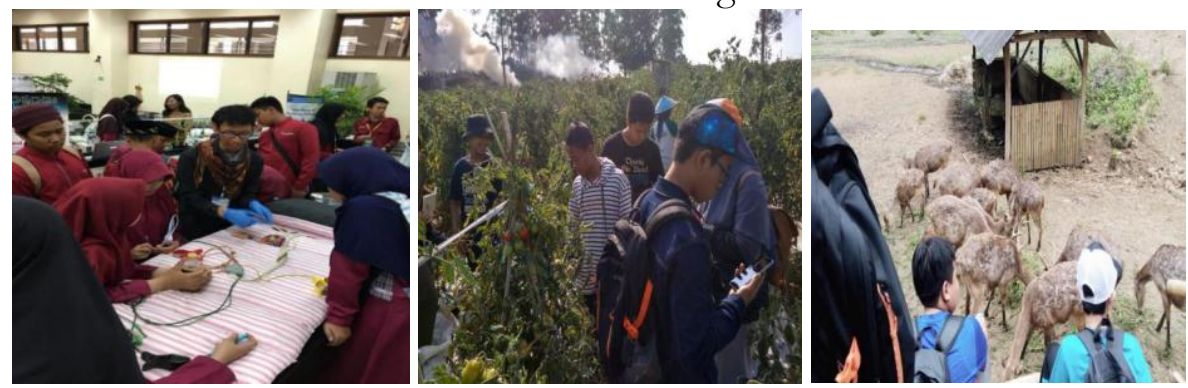

Kegiatan unggulan yang ada di pesantren ini merupakan sebuah kegiatan yang unik dan kreatif dalam mengembangkan keterampilan hidup, baik keterampilan bersikap, berkarya serta bertutur kata. ${ }^{34}$ Keterampilan ini ditujukan dalam rangka pembentukan karakter santri, sehingga santri dapat bersikap sesuai dengan nilai-nilai Islam berdasarkan pengalaman, pengetahuan serta teladan dari para pendidik. ${ }^{35}$ Para pendidik berkewajiban untuk senantiasa mewariskan nilai-nilai Islam karena sejatinya tujuan akhir pendidikan ialah membangun peradaban Islam yang kokoh ${ }^{36}$

\section{SIMPULAN}

Pesantren Kreatif IHAQI Boarding School Bandung merupakan salah satu lembaga pendidikan pesantren yang hadir di era revolusi industri 4.0. Pesantren ini mencoba memadukan berbagai teknologi modern dalam proses pembelajaran serta mengembangkan berbagai disiplin keilmuan dan keterampilan yang dibutuhkan tanpa menghilangkan nilai-nilai Islam, dengan visi agamis, universal dan kreatif, pesantren ini memiliki program pembinaan yang beragam dalam rangka membentuk karakter santri. Adapun program pembinaan yang disajikan

\footnotetext{
${ }^{34}$ Nurti Budiyanti, Asep Abdul Aziz, dan Palah. "The Formulation Of The Goal Of Insan Kamil As A Basis For The Development of Islamic Education Curriculum." IJECA (International Journal of Education and Curriculum Application) 3, no. 2 (2020), hlm. 110.

35 Nurti Budiyanti, Ahmad Syamsu Rizal, dan Elan Sumarna. "Implikasi Konsep Ūlūl 'Ilmi Dalam Al-Qur an Terhadap Teori Pendidikan Islam (Studi Analisis Terhadap Sepuluh Tafsīr Mu'Tabarah)." TARBAWY : Indonesian Journal of Islamic Education (2016), hlm. 51-75.

36 Ahmad Syamsu Rizal. "Perumusan Tujuan Sebagai Basis Pengembangan Kurikulum Pendidikan Islam.” Jurnal Pendidikan Agama Islam-Ta'lim 12, no. 02 (2014), hlm. 97-112.
} 
di Pesantren Kreatif IHAQI Boarding School ialah sebagai berikut: program KBM, pembiasaan karakter islami, pengembangan diri dan life skill, pembinaan mingguan, pembinaan bulanan, pembinaan kreatif, dan pembinaan kepesantrenan. Dari sejumlah rangkaian program yang disajikan terdapat program unggulan yang selalu dinantikan oleh seluruh santri juga orangtua santri yang ada di lingkungan pesantren. Terdapat dua program unggulan yang ada di Pesantren ini yakni workshop dan filed trip. Kegiatan unggulan yang ada di pesantren ini merupakan sebuah kegiatan yang unik dan kreatif dalam mengembangkan keterampilan hidup, baik keterampilan bersikap, berkarya serta bertutur kata. Keterampilan ini ditujukan dalam rangka pembentukan karakter santri, sehingga santri dapat bersikap sesuai dengan nilai-nilai Islam berdasarkan pengalaman, pengetahuan serta teladan dari para pendidik.

\section{DAFTAR PUSTAKA}

Abdullah, Anzar. "Madrasah di Indonesia dari Masa." Paramita 23, no. 2 (2013): 193-207.

Alwi, B. Marjani. "Pondok Pesantren: Ciri Khas, Perkembangan, dan Sistem Pendidikannya." Lentera Pendidikan: Jurnal Ilmu Tarbiyah dan Keguruan 16, no. 2 (2016): 205-219.

Anwar, Ahmad Masrul. "Pertumbuhan dan Perkembangan Pendidikan Islam Pada Masa Bani Ummayah.” Jurnal TARBIYA 1, no. 1 (2015): 47-76.

Aziz, Asep Abdul, Nurti Budiyanti Budiyanti, Nurwadjah Ahmad, Andewi Suhartini, dan Ari Prayoga. "Pendidikan Islam Sebagai Upaya Ma'rifatullah." Adaara: Jurnal Manajemen Pendidikan Islam 10, no. 2 (August 2020): 174-186.

Bashori, Bashori. "Modernisasi Lembaga Pendidikan Pesantren." Jurnal Ilmu Sosial Mamangan 6, no. 1 (2017): 47.

Budiyanti, Nurti, Asep Abdul Aziz, dan Palah. "The Formulation Of The

Goal Of Insan Kamil as a Basis For The Development of Islamic Education Curriculum." IJECA (International Journal of Education and Curriculum Application) 3, no. 2 (2020): 1-10.

Budiyanti, Nurti, Ahmad Syamsu Rizal, dan Elan Sumarna. "Implikasi Konsep Ūlūl 'Ilmi dalam Al-Qur'an Terhadap Teori Pendidikan Islam (Studi Analisis Terhadap Sepuluh Tafsīr Mu’Tabarah)." TARB AWY : Indonesian Journal of Islamic Education (2016): 51-75.

Busahdiar. "Dinamika Pendidikan di Pesantren." Misykat al-Anwar Jurnal Kajian Islam dan Masyarakat 27, no. 2 (2016): 1-12.

Herdiana, Iyus. "The Development of Character Education Model Based on Human's Natural Characteristics" (2013): 264-271.

Herman. "Sejarah Pesantren di Indonesia." Jurnal Al-Ta'dib 6, no. 2 
(2013): 145-158.

Jannah, Miftahul. "Metode dan Strategi Pembentukan Karakter Religius Yang Diterapkan di SDTQ-T An Najah Pondok Pesantren Cindai Alus Martapura." Al-Madrasab: Jurnal Pendidikan Madrasah Ibtidaiyah 4, no. 1 (2019): 77.

Kembara, Maulia Depriya, Rama Wijaya Abdul Rozak, dan Vini Agustiani Hadian. "Research-Based Lectures to Improve Students' 4C (Communication, Collaboration, Critical Thinking, and Creativity) Skills" 306, no. Isseh 2018 (2019): 22-26.

Lase, Delipiter. "Pendidikan di Era Revolusi Industri 4.0." SUNDERMANN: Jurnal Ilmiah Teologi, Pendidikan, Sains, Humaniora dan Kebudayaan (2019).

Maesaroh, Nenden, dan Yani Achdiani. "Tugas dan Fungsi Pesantren di Era Modern.” Sosietas 7, no. 1 (2018): 346-352.

Makmun, H.A. Rodli. "Pembentukan Karakter Berbasis Pendidikan Pesantren: Studi di Pondok Pesantren Tradisional dan Modern di Kabupaten Ponorogo." Cendekia: Jurnal Kependidikan dan Kemasyarakatan 12, no. 2 (2016): 211.

Miles, M. B., dan A. M. Huberman. Qualitative Data Analysis. Second Edi. London: SAGE Publications, Inc., 1994.

Moleong, Lexy J. "Metodologi Penelitian Kualitatif (Edisi Revisi)." In PT. Remaja Rosda Karya, 2017.

Musaddad Harahap. "Esensi Peserta Didik dalam Perspektif Pendidikan Islam." Jurnal Al-Thariqah Fakultas Agama Islam (FAI) Universitas Islam Riau (UIR) Pekanbaru Jl. Kaharuddin Nasution 1, no. 113 (2016): 140-155.

Nihwan. "Pendidikan Pesantren dalam Mempertahankan Nilai-Nilai Pendidikan Islam." Jurnal Studi Keagamaan, Pendidikan dan Humaniora 4, no. 1 (2017): 151-165.

Parhan, Muhamad, Aiman Faiz, Abdul Karim, Risris Hari Nugraha, Ganjar Eka Subakti, Mohammad Rindu, Fajar Islamy, Nurti Budiyanti, Ahmad Fuadin, dan Yusuf Ali Tantowi. "Internalization Values of Islamic Education At University." International Journal of Psychosocial Rehabilitation 24, no. 08 (2020): 14778-14791.

Prayoga, Ari, Irawan Irawan, dan Ahmad Rusdiana. "Karakteristik Program Kurikulum Pondok Pesantren." Jurnal Pendidikan dan Pendidikan Agama Islam 02, no. 01 (June 2020): 77-86. http://ejournal.uniks.ac.id/index.php/Alhikmah/article/view/4 24.

Prayoga, Ari, and Mohammad Sulhan. "Pesantren Sebagai Penangkal Radikalisme dan Terorisme." Dirasat: Jurnal Manajemen dan 
Pendidikan Islam 5, no. 2 (December 2019): 163-177.

Rifa'i, Muh. Khoirul. "Internalisasi Nilai-Nilai Religius Berbasis Multikultural dalam Membentuk Insan Kamil." Jumal Pendidikan Agama Islam (Journal of Islamic Education Studies) (2016): 116-133.

Rizal, Ahmad Syamsu. "Perumusan Tujuan Sebagai Basis Pengembangan

Kurikulum Pendidikan Islam." Jurnal Pendidikan Agama IslamTa'lim 12, no. 02 (2014): 97-112.

Septikasari, Resti, dan Rendy Nugraha Frasandy. "Keterampilan 4C Abad 21 Dalam Pembelajaran Pendidikan Dasar." Tarbiyah AlAwlad VIII, no. 2 (2018): 112-122.

Shofiyyah, Nilna Azizatus, Haidir Ali, dan Nurhayati Sastraatmadja. "Model Pondok Pesantren Di Era Milenial." BELAJEA: Jurnal Pendidikan Islam 4, no. 1 (2019): 1.

Siregar, Andre Syahbana. "Sejarah Perkembangan Sistem Pendidikan Islam di Pesantren Ar-Raudlatul Hasanah Kota Medan." JUSPI Jurnal Sejarah Peradaban Islam) 2, no. 1 (2018): 113.

Sugiyono. Metode Penelitian Kuantitatif, Kualitatif Dan R\&D. 24th ed. Bandung: Alfabeta, 2016.

Suhartini, Andewi. "The Internalization of Islamic Values in Pesantren." Jurnal Pendidikan Islam (2016).

Sulaiman, Rusydi. "Hakikat Pendidikan Pesantren." Edugama: Jurnal Kependidikan dan Sosial Keagamaan 5, no. 1 (2019): 1-29.

. "Pendidikan Pondok Pesantren: Institusionalisasi Kelembagaan Pendidikan Pesantren." 'Anil Islam 9, no. 1 (2016): 148-174.

Syafe'i, Imam. "Pondok Pesantren: Lembaga Pendidikan Pembentukan Karakter." Al-Tadzkiyyah: Jurnal Pendidikan Islam 8, no. 1 (2017): 61.

Tolib, Abdul. "Pendidikan di Pondok Pesantren Modern Terpadu." Risalab 1, no. 1 (2015): 60-66.

Ulfah, Humaira, Edi Suresman, dan Abas Asyafah. "Studi Realitas Implementasi Kurikulum 2013 Pada Mata Pelajaran PAI dan Budi Pekerti Jenjang SMA (Studi Deskriptif Pada Berbagai Klasifikasi Guru SMA Di Kota Bandung Tahun 2015).” TARB AWY : Indonesian Journal of Islamic Education (2015).

Zulhimma. "Dinamika Perkembangan Pondok Pesantren di Indonesia." Jurnal Darul 'Ilmi 01, no. 02 (2013): 166-167. 